\title{
OPCJE REALNE JAKO ALTERNATYWA W WYCENIE PROJEKTÓW INWESTYCYJNYCH
}

\author{
Michał Gnap \\ Uniwersytet Rzeszowski
}

\begin{abstract}
Abstrakt. Podstawą funkcjonowania każdej firmy jest stosowanie podejścia value-based management. W myśl tej koncepcji konieczna jest umiejętność podejmowania działań zarówno o charakterze operacyjnym, jak i inwestycyjnym, które są ukierunkowane na wzrost określonych wielkości ekonomicznych w przyszłości. Aktualnie powszechnie używane miary efektywności inwestycji, np. NPV, IRR, nie do końca są adekwatnymi narzędziami do oceny efektywności inwestycji w obecnych turbulentnych warunkach rynkowych. Wszystkie niedoskonałości i ograniczenia charakteryzujące wyżej wymienione metody powodują, że kadra zarządzająca bardzo często podejmuje decyzje inwestycyjne intuicyjnie. Standardowa analiza NPV powinna być więc poszerzona o użycie dodatkowych narzędzi, jakimi są opcje realne. Celem niniejszej pracy nie jest scharakteryzowanie metod wykorzystywanych do szacowania opcji realnych, a zobrazowanie, w jaki sposób przedsięwzięcia z pozoru nieopłacalne poprzez wykrycie w nich możliwości elastycznego reagowania stają się inwestycjami, które mogą przynieść firmom ponadproporcjonalne zyski.
\end{abstract}

Słowa kluczowe: opcje realne, wartość bieżąca netto, instrumenty finansowe

\section{WSTĘP}

Zgodnie z obecnie przeważającym poglądem [Damodaran 1997, Mielcarz 2015, Panfin 2015] głównym elementem zarządzania przedsiębiorstwem jest podejmowanie decyzji inwestycyjnych ukierunkowanych na maksymalizację określonych wielkości ekonomicznych w przyszłości. Do tychże wielkości przede wszystkim należałoby zaliczyć zysk, który jest bezwzględną miarą efektywności danego 
przedsiębiorstwa. Z uwagi na to, że realizacje przedsięwzięć inwestycyjnych ma duży wpływ na możliwości generowania nadwyżki finansowej, analiza tych przedsięwzięć powinna obejmować bardziej skomplikowane narzędzia analityczne. W tym momencie może nasuwać się pytanie, jakie narzędzia obrać, jakie metody stosować i jakimi kryteriami się kierować, aby efektywnie przeprowadzić analizę możliwości inwestycyjnych przedsiębiorstwa. W związku z powyższym można łatwo dojść do konkluzji, że nie ma jednego uniwersalnego algorytmu, którego możliwości zastosowania obejmowałby wszystkie przypadki. Analizując historię jako magistra vitae, można zaobserwować, że tylko przedsiębiorstwa, których działalność miała wysoki poziom innowacyjności, które korzystały z pionierskich rozwiązań, a ich bieżące funkcjonowanie cechowało się pewnego rodzaju niekonwencyjnością, generowały ponadprzeciętne dochody.

Dla ekonomisty jednym z pionierskich poglądów odnoszących się do zasad gospodarowania przedsiębiorstwem niewątpliwie może być pogląd Arystotelesa dotyczący gospodarowania. Filozof wyodrębnił trzy działy nauki gospodarowania:

1. Oikonomikos jako nauka o gospodarowaniu, obejmująca umiejętność zarobkowania z dodatkowych źródeł.

2. Chrematystyka, czyli umiejętność pozyskiwania i gromadzenia pieniądza (w drodze wymiany).

3. Ostatnia część odnosiła się do nauki po pieniądzu. Kontynuowała ona rozważania Ksenofonta w dziedzinie sposobu porównywania wartości różnych dóbr za pomocą pieniądza [Panfil i Szablewski 2015].

Powyższe poglądy w przekonaniu autora niewątpliwie bardzo dobrze obrazują podstawowe umiejętności, które powinni posiadać współcześni menadżerowie, jednakże trudniejszą sztuką jest samo odnalezienie określonej możliwości inwestycyjnej. Nawet na pierwszy rzut oka genialny pomysł powinien był dokładnie przeanalizowany pod kątem opłacalności, bowiem w praktyce może okazać się, że jest opłacalnym, ale z uwagi na luki w generowania wolnych przepływów pieniężnych przez przedsiębiorstwo niemożliwy do zrealizowania. Analiza opłacalności racjonalności finansowej danego przedsięwzięcia finansowego wbrew powszechnemu przekonaniu powinna więc dawać podstawę do stosowania bardziej zaawansowanych technik, jakim jest m.in. wykorzystanie opcji realnych [Copeland i Antikarov 2001].

Ideę opcji realnych stworzył Stewart Mayers, który w 1977 roku wprowadził nowy termin real option. Pojęcie to określa dodatkowe, bliżej niezidentyfikowane korzyści z projektu inwestycyjnego. Koncepcja ta pomimo coraz większego znaczenia teoretycznego, w praktyce gospodarczej pojawiła się dopiero na początku lat 90. XX wieku. W okresie bieżącym opcje realne uznaje się za rewolucyjne, choć ze względu na swój problematyczny charakter mogą być trudne do zidentyfikowa- 
nia. Jednakże ich rozpoznanie pozwala wyeliminować problem niedoszacowania projektów inwestycyjnych obarczonych wysokim poziomem ryzyka [Mielcarz i Paszczyk 2015]. Artykuł ten ma na celu analizę wpływu opcji realnych w wycenie projektów inwestycyjnych.

\section{OPCJE REALNE W PROJEKTACH INWESTYCYJNYCH}

Cechą charakterystyczną projektów inwestycyjnych są ponadnormalne, w stosunku do bieżącego prowadzenia działalności gospodarczej, możliwości generowania wolnych przepływów pieniężnych, które obarczone są wysokim stopniem ryzyka oraz dużą dozą niepewności [Boer 2002]. Stosunkowo długi horyzont planowania oraz ryzyko wpisane $w$ przeprowadzanie projektów inwestycyjnych może tworzyć wiele bardzo wartościowych opcji elastycznego reagowania kadry menadżerskiej na zmieniające się warunki inwestycyjne [Pennings i Lint 1997]. Bardzo trafnie istotę problemu opcji realnych oddaje definicja podana przez Amram oraz Kalitulake'a: „opcja realne jest prawem do podjęcia w przyszłości jakiegoś działania, którego wartość bieżąca, podobnie jak opcja zakupu czy sprzedaży instrumentu finansowego, jest tym większa im większe jest ryzyko rozwoju sytuacji w sposób niezgodny z pierwotnie planowanym" [Amram i Kalitulake 1999].

W tym miejscu należałoby pokrótce odnieść się do metody dochodowej wyceny przedsiębiorstw (DCF - ang. discounted cash flow), która bardzo często jest używana dla projektów inwestycyjnych z wykorzystaniem NPV. Zakłada ona z góry pasywność realizowanego przedsięwzięcia inwestycyjnego przez firmę. Innymi słowy, kadra zarządzająca ignoruje wykorzystanie zawartej w projekcie elastyczności decyzyjnej przejawiającej się poprzez opcje realne. W związku z powyższym można pokusić się o stwierdzenie, iż metoda DCF nie odzwierciedla wartość zarządzania projektem. Kadra zarządzająca, która wykorzystuje zawarte w projekcie opcje realne, może poprzez swoje decyzje wypracować dodatnia wartość wynikająca z kontynuacji/porzucenia projektu, przy jednoczesnym zmniejszaniu lub całkowitej redukcji straty wynikającej z realizacji skrajnie niekorzystnego scenariusza wydarzeń [Myers i in. 2014]. Z kolei wartość bieżąca netto, jak również zysk ekonomiczny ignorują w sposób bezsprzeczny bardzo istotną rzeczywistość: decyzje inwestycyjne $\mathrm{w}$ wielu branżach oraz sytuacje $\mathrm{w}$ nich występujące mogą sugerować swobodę podejmowania decyzji dotyczących odroczenia, odrzucenia lub poszerzenia z podziałem na poszczególne etapy projektu, co świadczy o zawartych w nich opcjach realnych. Rozpoznanie tychże opcji realnych może pomóc w ocenie rentowności nowych możliwości projektu oraz umożliwi zrozumienie, gdzie i kiedy takie działania podejmować. Wykorzystanie tego narzędzia może być niezwykle użyteczne w szczególności w projektach, które charakteryzują się wysokim stopniem ryzyka [Copeland i Keenan 1998a]. 
Opcje realne najogólniej można podzielić na opcje typu call - wariant rozszerzenia projektu, typu put - zaprzestanie projektu, sprzedaż aktywów oraz opcje złożone, np. etapowej realizacji projektu, w której podjęcie kolejnego etapu jest uzależnione od wyników etapu poprzedniego [Mielcarz i Paszczyk 2015]. W literaturze natomiast można odnaleźć opisy kilkunastu opcji realnych oraz ich kombinacji [Mielcarz i Paszczyk 2015, Panfil i Szablewski 2015], jednakże charakterystyka ich wszystkich przekracza zakres przedmiotowego artykułu.

Zobrazowanie problemów związanych z wyceną opcji realnych zawartych w projektach inwestycyjnych wymaga niewątpliwe omówienie różnic między tymi instrumentami a opcjami finansowymi. Najistotniejsza co do zasady różnica, pociągająca za sobą istnienie także innych dotyczy instrumentu bazowego, którym w przypadku opcji realnych jest wartość brutto projektu. Ceną wykonania jest analogicznie wysokość nakładów inwestycyjnych potrzebnych do uzyskania wartości netto projektu. W przypadku opcji typu put wartością wykonania jest możliwa do uzyskania wielkość z tytułu odsprzedaży lub wstrzymania realizacji projektu.

Do pozostałych różnic dzielących oba instrumenty możemy zaliczyć:

1. Brak wyłączności posiadania opcji realnej. Pochodne instrumenty finansowe, czy są to kontrakty futures, czy opcje na akcje, dają właścicielowi tychże opcji niezależności ich wykonania w stosunku do innych inwestorów.

2. Brak możliwości sprzedaży opcji. Art. 18 ustawy o obrocie instrumentami finansowymi stanowi, że spółka prowadząca giełdę lub rynek pozagiełdowy zapewnia: „koncentrację popytu i podaży na instrumenty finansowe, będące przedmiotem obrotu na danym rynku, w celu kształtowania ich powszechnego kursu" [Ustawa z dnia 29 lipca 2005 r. o obrocie instrumentami finansowymi].

3. Aktywo bazowej opcji realnej nie jest przedmiotem obrotu [Rogowski 2008].

Konsekwencją sytuacyjnego charakteru opcji realnych jest możliwość wpływania na ich wartość podejmowanymi decyzjami. Można z tego wyciągnąć wniosek, że popełnianie błędów w zarządzaniu przedsiębiorstwem może doprowadzić do znacznego obniżenia się ich wartości. Aktywne zarządzanie, umiejętność podejmowania bieżących decyzji gospodarczych mogą równocześnie doprowadzić do pojawienia się nowych opcji elastycznego reagowania lub zwiększenia wartości tych już dostępnych [Copeland i Keenan 1998b].

W odróżnieniu od opcji finansowych opcje realne nacechowane są problemem czasu niezbędnego do wykonania opcji. Realizacja fazy inwestycyjnej jest czasochłonna, co oznacza, że przewidywane wolne przepływy pieniężne zarówno ujemne, jak i dodatnie, które są efektem wytworzenia określonego zasobu majątkowego, są znacząco odsunięte w czasie. Ponadto długi czas niezbędny do 
wykonania jej opcji zmniejsza jej wartość. Jest to zgodne z zasadami matematyki finansowej, bowiem jeżeli wartość wolnych przepływów w późniejszych okresach jest większa, ich wpływ słabiej oddziałuje na wartość projektu [Damodaran 1997]. Specyficzną cechą opcji realnych jest również ich podatność na działania konkurencyjne. Nieprzewidywalne zmiany rynkowe w stosunku do planu bazowego, czyli takiego, jakiego firma uznała za najbardziej prawdopodobny wariant do spełnienia, mogą doprowadzić do całkowitego zaniku danej opcji, lub też stworzyć całkiem nowe opcje [Mun 2002].

Jeżeli to projekt ma dużą wartość bieżącą netto to, przeprowadzanie dodatkowych analiz obejmujących wycenę opcji realnych nie ma ekonomicznego sensu, ponieważ opcje elastycznego reagowania mogę jedynie podnieść wartość projektu. Jednocześnie projekt charakteryzujący się bardzo dużą ujemną wartością bieżącą netto z punktu widzenia idei uwzględniania opcji realnych również nie powinien być poddawany dodatkowej analizie z uwzględnieniem opcji elastycznego reagowania. Oszacowanie wpływu elastyczności działania nie zmienia z reguły oceny racjonalności projektu, a tym samym decyzji o jego dorzuceniu [Copeland i Antikarov 2001].

\section{ANALIZA PRZYPADKU. WYCENA PROJEKTU INWESTYCYJNEGO Z UWZGLĘDNIENIEM OPCJI ELASTYCZNEGO REAGOWANIA}

W celu zachowania istoty zaprezentowanego przykładu w opisie przedstawiono tylko i wyłącznie dane niezbędne do zobrazowania metodyki wyceny opcji realnych. Pominięto zatem zagadnienia związane z procesem szacowania zmiennych bazowych, analizę rynku. Przedstawiono ponadto proces obliczeniowy obejmujący symulację Monte Carlo oraz wycenę zawartych w projekcie opcji za pomocą analiz drzew Coxa, Rossa i Rubinsteina.

Kadra zarządzająca przedsiębiorstwem Omega S.A., rozpatruje możliwość rozpoczęcia działalności gospodarczej na nowym rynku. Wymagana kwota nakładów inwestycyjnych koniecznych do poniesienia wynosi 12,35 mln PLN. Pierwszy etap przedsięwzięcia będzie miał charakter badawczy. Wymaga to poniesienia $4 \mathrm{mln}$ PLN na otwarcie kilku punktów handlowych w celu rozpoznania rynku. Druga część, która obejmuje wybudowanie pełnej sieci produkcji, będzie kosztować 8,35 mln PLN. Z przeprowadzonej analizy eksperckiej wynika, że wartość przychodów w najbardziej prawdopodobnym scenariuszu wyniesie 3,3 mln PLN, a w drugim 3,6 mln PLN. Wstępne badania dowiodły, że odchylenie standardowe dla przychodów wyniesie 40\%, a kosztów 20\%. Przewidziano również, że po trzecim roku projekt będzie generował wolne przepływy pieniężne w niedającym się określić czasie na poziomie 1,1 mln PLN. Powyższe podejście jest bowiem zgodne 
z koncepcją wartości końcowej (TV - ang. terminal value). Zwolennicy wersji zachowawczej wskazują bowiem na fakt, iż każdy rynek osiąga w końcu fazę dojrzałości. W takiej sytuacji kontynuację traktuje się jak rentę wieczystą. Średni ważony koszt kapitału znajduje się na poziomie $10 \%$, stopa wolna od ryzyka to $5 \%$.

\section{Rozwiqzanie}

Zgodnie z założeniami standardowej procedury obliczenia wartości bieżącej netto wartość przedsięwzięcia inwestycyjnego powinna zostać oszacowana w sposób wskazany w tabeli 1.

TABELA 1. Kalkulacja wolnych przepływów pieniężnych (tys. PLN)

\begin{tabular}{|l|c|c|c|}
\hline Okres & 0 & 1 & 2 \\
\hline Przychody & $\times$ & 3300 & 3600 \\
\hline $\begin{array}{l}\text { Wydatki operacyjne związane z prowadzoną działal- } \\
\text { nością }\end{array}$ & $\times$ & -2150 & -2250 \\
\hline Nakłady inwestycyjne & -4000 & -8350 & $\times$ \\
\hline FCF (wolne przepływy środków pieniężnych) & -4000 & -7200 & 1350 \\
\hline
\end{tabular}

Źródło: Opracowanie własne.

Wartość bieżąca netto:

$$
N P V=-4000+\frac{-7200}{(1+0,1)}+\frac{1350}{(1+0,1)^{2}}+\frac{1100: 0,1}{(1+0,1)^{2}}=-338,84 \text { tys. PLN }
$$

Z przedstawionej kalkulacji wynika, iż projekt jest nieopłacalny, ponieważ jego wartość oczekiwanych korzyści jest mniejsza od zaktualizowanych na moment zerowy nakładów inwestycyjnych. W tym momencie, przyjmując wartość NPV jako wartość ostatecznie decydującą o zasadności realizacji przedsięwzięcia, projekt ten należałoby odrzucić. Warto jednak zaznaczyć, iż w tym konkretnym przypadku samo wyliczenie wartości bieżącej netto nie jest wystarczającym narzędziem do wyceny tego typu przedsięwzięć inwestycyjnych. Dzieli się ono bowiem na dwa etapy. Pierwszy z nich ma charakter badawczy. Jego celem jest bowiem zdobycie cennych informacji o warunkach funkcjonowania wcześniej nieznanego rynku. Biorąc więc pod uwagę specyfikę projektu, użycie standardowej metody NPV bez zastosowania dodatkowych narzędzi może doprowadzić do znacznego niedoszacowania wartości projektu i w konsekwencji do jej nieuzasadnionego odrzucenia [Luehrman 1998]. Przyjęto, iż na etapie drzewa zdarzeń zostanie wykorzystana metodyka Coxa, Rossa i Rubinsteina.

Oszacowanie standardowego odchylenia stopy zwrotu z projektu przeprowadzono za pomocą symulacji Monte Carlo. Posłużona się założeniami przedstawionymi w tabeli 2 . 
TABELA 2. Parametry zmiennych bazowych

\begin{tabular}{|l|c|c|c|c|}
\hline Dane & Średnia & $\begin{array}{c}\text { Odchylenie } \\
\text { standardowe }\end{array}$ & $\begin{array}{c}\text { Rozkład } \\
\text { prawdopodobień- } \\
\text { stwa }\end{array}$ & $\begin{array}{c}\text { Zakres } \\
\text { wartości }\end{array}$ \\
\hline $\begin{array}{l}\text { Przychody w roku } \\
\text { pierwszym }\end{array}$ & 3300 & 1320 & normalny & od 0 do $+\infty$ \\
\hline Przychody w roku drugim & 3600 & 1400 & normalny & od 0 do $+\infty$ \\
\hline $\begin{array}{l}\text { Udział wydatków operacyj- } \\
\text { nych w przychodach w roku } \\
\text { pierwszym }\end{array}$ & $64 \%$ & $20 \%$ & normalny & od 0 do $+\infty$ \\
\hline $\begin{array}{l}\text { Udział wydatków operacyj- } \\
\text { nych w przychodach w roku } \\
\text { drugim }\end{array}$ & $62 \%$ & $20 \%$ & normalny & od 0 do $+\infty$ \\
\hline
\end{tabular}

Źródło: Opracowanie własne.

Na rysunku 1 zaprezentowano wykres rozkładu prawdopodobieństwa stopy zwrotu, a elementy statystyki zawiera tabela 3.

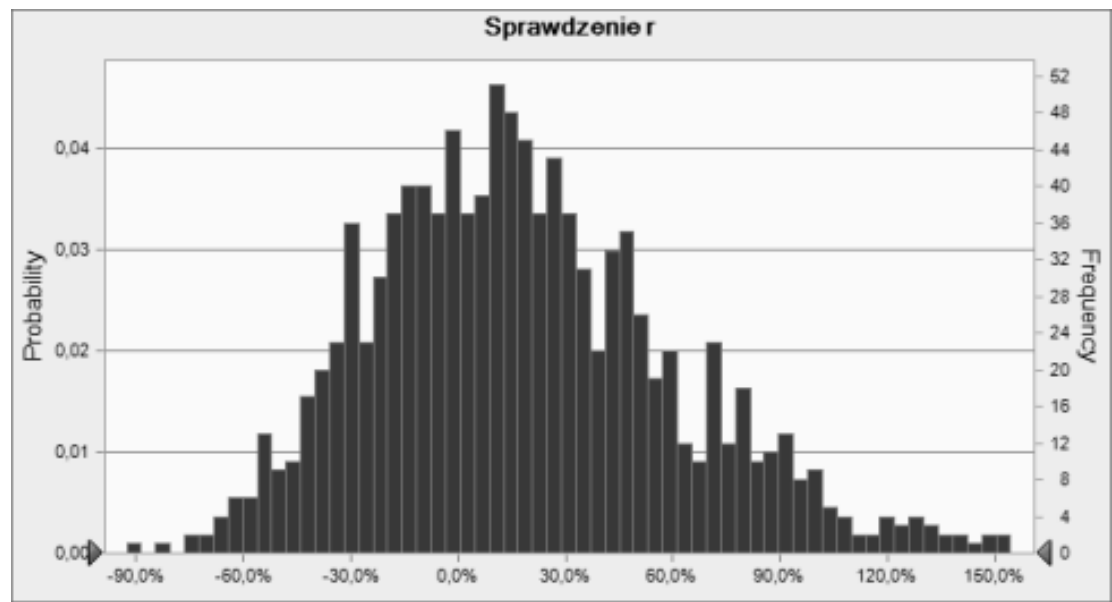

RYSUNEK 1. Rozkład prawdopodobieństwa stopy zwrotu bez elastyczności działania i nakładów inwestycyjnych

Źródło: Opracowanie własne.

Z przeprowadzonych obliczeń wynika, że standardowe odchylenie stopy zwrotu znajduje się na wysokim poziomie i wynosi 48\%. Biorąc pod uwagę tę wielkość, możemy wyliczyć poziom wskaźnika wzrostu wartości projektu $u$, oraz wskaźnika spadku wartości projektu $d$ :

$$
\begin{gathered}
u=e^{0,4821 \sqrt{ } 1}=1,6160 \% \\
d=e^{-0,4821 \sqrt{1}}=\frac{1}{1,6160}=0,6187 \% .
\end{gathered}
$$


Tabela 3. Statystka symulacji stopy zwrotu

\begin{tabular}{|l|c|}
\hline Wybrane statystyki & Prognozowane wielkości \\
\hline Próba & 1102 \\
\hline Wariant bazowy & $9,5 \%$ \\
\hline Średnia & $19,9 \%$ \\
\hline Mediana & $14,0 \%$ \\
\hline Odchylenie standardowe & $48,0 \%$ \\
\hline Wariancja & $23,1 \%$ \\
\hline Skośność & 1,82 \\
\hline Kurtoza & 14,57 \\
\hline Współczynnik zmienności & 2,41 \\
\hline Wielkość minimalna & $-92,6 \%$ \\
\hline Wielkość maksymalna & $499,1 \%$ \\
\hline Rozstęp & $591,7 \%$ \\
\hline Błąd standardowy & $1,4 \%$ \\
\hline
\end{tabular}

Źródło: Opracowanie własne.

Określenie wartości wskaźników $d$ i $u$ oraz wskaźnika wypłaty wolnych przepływów pieniężnych, który dla pierwszego roku wynosi 7,8\%, a dla drugiego 9,1\%, pozwala oszacować wartość projektu przed wypłatą wolnych przepływów pieniężnych:

$$
\begin{gathered}
V_{u}=52523,17 \text { tys. PLN } \\
V_{d}=8241,06 \text { tys. PLN }
\end{gathered}
$$

Na podstawie tak oszacowanych wartości projektu oraz wskaźnika wypłat w danym okresie możemy ustalić kwoty wypłat wolnych przepływów:

$$
\begin{gathered}
F C F_{u 1}=1689,53 \text { tys. PLN } \\
F C F_{d 1}=153,59 \text { tys. PLN }
\end{gathered}
$$

Kolejnym etapem kalkulacji jest ustalenie prawdopodobieństwa wystąpienia scenariuszy rozwoju sytuacji:

$$
p=\frac{(1+0,1)-0,6187}{(1,6160-0,6187)}=48,3 \%
$$

Prawdopodobieństwo wzrostu wartości projektu wynosi 48,3\%, a spadku $51,7 \%$. Analiza wartości projektu prowadzi do wniosku, że w przypadku materializacji scenariusza pesymistycznego po pierwszym roku trwania projektu jego wartość po wypłacie wolnych przepływów pieniężnych wyniesie 8087,47 tys. PLN 
i będzie mniejsza od niezbędnych nakładów na realizacji drugiego etapu inwestycji. W związku z powyższym racjonalnie postępująca kadra podejmie decyzję o zaprzestaniu projektu. Wpływ tej decyzji na wartość projektu jest przedstawiony za pomocą drzewa decyzyjnego przedstawionego na rysunku 2.

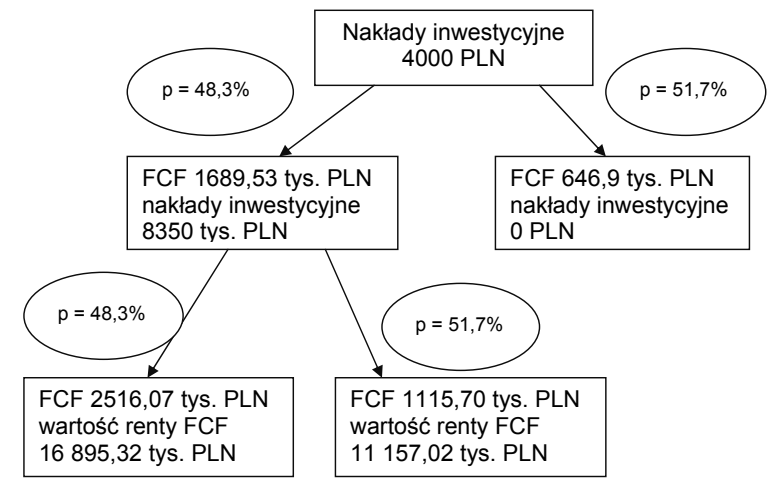

$p$ - prawdopodobieństwo

RYSUNEK 2. Drzewo decyzyjne dla projektu inwestycyjnego

Źródło: Opracowanie własne.

Drzewo przedstawione na rysunku 2 pozwala na wyznaczenie wartości projektu, z uwzględnieniem elastyczności działania:

$$
\begin{aligned}
& N P V=4000+\frac{(1689,53-7200) \cdot 0,483+649,9 \cdot 0,517}{(1+0,1)}+ \\
& +\frac{(2516+16895,32) \cdot(0,483)^{2}+(1115,7+11157,02) \cdot 0,483 \cdot 0,517}{(1+0,1)^{2}}=154,86 \text { tys. PLN }
\end{aligned}
$$

Biorąc pod uwagę, że wartość projektu bez elastyczności działania oszacowano na poziomie -338,84 tys. PLN, wartość elastycznego działania wyznaczona metodą drzew decyzyjnych wynosi 154,86 tys. PLN. Powyższe świadczy o tym, że w przypadku użycia drzewa decyzyjnych $w$ analizie projektu możliwe jest uwzględnienie różnych scenariuszy działania, rozwoju sytuacji czy podejmowania działań adaptacyjnych na każdym z etapów realizacji danego przedsięwzięcia inwestycyjnego.

\section{WNIOSKI}

Koncepcja opcji realnej to niewątpliwie duży postęp w wycenie projektów inwestycyjnych. Pomimo że w literaturze przedmiotu pojawiła się w latach 70. XX wieku dzięki profesorowi Mayersowi, na chwilę obecną ze względu na swój charakter problematyka ta jest trudna do zidentyfikowania. Powoduje to sytuację 
paradoksalną z ekonomicznego punktu widzenia. Przedsięwzięcia inwestycyjne, które mogłyby być podejmowane, bardzo często są odrzucane przez kadrę zarządzającą, która kieruje się kryterium maksymalizacji wartości bieżącej netto, nie zwracając uwagi na ukryte w analizowanych przedsięwzięciach inwestycyjnych wartościowe opcje elastycznego reagowania. Ich problematyczny charakter wynika głównie z metodyki wyceny. W odróżnieniu od opcji finansowych, w których nabywca, jeżeli nie jest dużą instytucją finansową, nie ma możliwości wpływania na ich wartość. W przypadku opcji realnych zarząd poprzez podejmowane przez siebie decyzje wpływa niemalże w 100\% na wartość konkretnego przedsięwzięcia inwestycyjnego. Dzięki zastosowaniu opcji realnych ryzyko projektu, które w standardowej metodzie szacowania wartości bieżącej netto uważane jest za czynnik tylko i wyłącznie negatywny, daje decydentom możliwość elastycznego reagowania. W warunkach postępującej globalizacji oraz swobodzie przepływów kapitałów właśnie ta elastyczność reagowania stanowi fundament dobrze prosperującego przedsiębiorstwa. Oczywiście należałoby w tym momencie przyznać, iż nigdy nie zabraknie ludzi, którzy swoje decyzje inwestycyjne podejmują w sposób intuicyjny. Należy zadać sobie więc pytanie, dokąd taki sposób postępowania może doprowadzić gospodarkę kraju z makroekonomicznego punktu widzenia.

\section{Spis literatury}

AMRAM M., KALITULAKE N. 1999: Real Options, Managing Strategic Investment in an Uncertain Word, Harvard Business School Press, Boston.

BOER F.P. 2002: Financial management of R\&D, Research-Technology Management, 45 (4), 23-35.

COPELAND T., ANTIKAROV V. 2001: Real Options: A Practitioner's Guide, Texere, New York.

COPELAND T.E., KEENAN P.T. 1998a: How much is flexibility worth?, The McKinsey Quarterly 2, 38-50.

COPELAND T.E., KEENAN P.T. 1998b: Making real options real, The McKinsey Quarterly 1 (3), 128-142.

DAMODARAN A. 1997: Corporate Finance: Theory and practice, John Wiley \& Sons, New York.

MIELCARZ P., PASZCZYK P. 2015: Analiza projektów inwestycyjnych w procesie tworzenia wartości przedsiębiorstwa, Wydawnictwo Naukowe PWN, Warszawa.

MYERS S., BREALEY R., ALLEN F. 2014: Principles of Corporate Finance, Wydawnictwo Mc Graw Hill, New Delhi.

MUN J. 2002: Real Options Anlysis: Tools and techniques for valuing strategic investments and decisions, John Wiley \& Sons, Hoboken.

LUEHRMAN T.A. 1998: Strategy as a portfolio of Real Options, Harvard Business Review. 
PANFIL M., SZABLEWSKI A. 2015: Wycena przedsiębiorstw. Od teorii to praktyki, Poltex, Warszawa.

PENNINGS E., LINT O. 1997: The option value of advanced R\&D, European Journal of Operational Research 103 (1), 83-94.

ROGOWSKI W. 2008: Opcje realne w przedsięwzięciach inwestycyjnych, Wydawnictwo SGH, Warszawa.

Ustawa z dnia 29 lipca 2005 r. o obrocie instrumentami finansowymi. Dz.U. 2005 nr 183, poz. 1538.

\title{
REAL OPTION AS AN ALTERNATIVE IN THE VALUATION OF INVESTMENT PROJECT
}

\begin{abstract}
The most important function of every company is to create value for its owners. In this concept, it is necessary to make actions both operating and investing. They are targeted to increase economical value in the future. Very popular in this age net present value and internal rate of return, even though very popular, they face absolute tool. Every limitation which is typical for those methods, lead to situations where management must take decisions intuitively. So standard analysis NPV should be expanded by additional tools like the real option. The aim of this work is not to characterize approaches used for estimation of real option value, but to show how seemingly unprofitable investments can be profitable due to feature real options which can bring to company over-proportional profit.
\end{abstract}

Key words: real option, net present value, financial instruments 